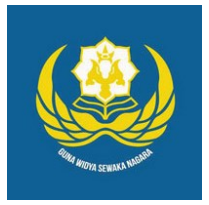

Warmadewa Economic Development Journal

\title{
Pengaruh Capital Adequancy Ratio, Net Interest Margin,Biaya Operasional Pendapatan Operasional Dan Loan Deposit Ratio Terhadap Non Performing Loan Di Pt. Bank Pembangunan Daerah Bali Tahun 2009 - 2017
}

Ni Wayan Eka Yuliani*, A.A. Sri Purnami dan I Gusti Ayu Athina Wulandari

Fakultas Ekonomi, Universitas Warmadewa, Denpasar, Bali

*ekayuliani13@gmail.com

\begin{tabular}{ll}
\hline A B S T R A C T & A R T I C L E I N F O \\
\hline NPL is one indicator in assessing the soundness of banks. This study & How To Cite: \\
aims to examine the effect of CAR, NIM, BOPO and LDR on Non & Yuliani, N, W, E., Purnami, A, A, S., \\
Performing Loans at PT. Regional Development Bank of Bali in the & Wulandari, I, G, A, A. (2020). Pengaruh \\
count of I - IV in 2009 - 2017 using multiple linear analysis methods. & Capital Adequancy Ratio, Net Interest \\
The results of this study produce an F Test which all independent & Margin,Biaya Operasional Pendapatan \\
variables (CAR, NIM, BOPO and LDR) have a liner / influence with & Operasional Dan Loan Deposit Ratio \\
NPL variables and partially, CAR has a significant and significant & Terhadap Non Performing Loan Di Pt. \\
effect on NPL, NIM has a positive and not significant effect on NPL, & Bank Pembangunan Daerah Bali Tahun \\
influential BOPO positive and significant effect on NPL and LDR & 2009-2017.Warmadewa Economic \\
positive and not significant effect on NPL. & Development Journal. 3(1). 10-20. Doi: \\
https://doi.org/10.22225/ \\
& wedj.3.1.1590.10-20 \\
& \\
& Keywords: \\
& BOPO, \\
& CAR, \\
LDR
\end{tabular}

\section{PENDAHULUAN}

Bank merupakan badan usaha dimana kegiatan usahanya, yakni menghimpun dana dari masyarakat dalam bentuk simpanan dan menyalurkannya kembali dana tersebut kepada masyarakat yang membutuhkannya.Salah satu fungsi bank umum adalah menyediakan alat pembayaran yang sah, dalam hal ini uang yang diperoleh dari penghimpunan dana dan menyalurkan dana tersebut kepada masyarakat yang memerlukan dana. Peranan bank sebagai lembanga keuangan tidak pernah luput dari masalah kredit. Sumber pendapatan utama bank adalah kegiatan penyaluran kredit. Semakin besar jumah kredit yang di salurkan, maka akan membawa konsekuensi semakin besar resiko yang harus ditangguang oleh bank yang bersangkutan.
Non Performing Loan (NPL) merupakan rasio yang di gunakan untuk mengukur kemampuan bank dalam men-cover risiko kegagalan pengambilan kredit oleh debitur. NPL mencerminkan risiko kredit, semakin tinggi tingkat NPL maka semakin besar pula risiko kredit yang ditanggung oleh pihak bank (Ali, 2004). Prediksi terjadinya Non Performing Loan dapat dilihat dari beberapa faktor diantaranya Loan Deposit Ratio (LDR), Capital Adequacy Ratio (CAR), Net Interest Margin (NIM), dan Biaya Operasional terhadap Pendapatan Operasional (BOPO).

Di Provinsi Bali terdapat beragam jenis Bank Umum,yakni Bank Milik Negara, Bank Milik Swasta Bank Multiasional, dan juga Bank Milik Daerah. Bank Milik Daerah yakni BPD Bali. BPD Bali Merupakan satu-satunya Bank Umum milik Daerah yang slogannya "Bersama 
Membangun Bali”. Kegiatan BPD Bali yaitu menyalurkan dana kepada masyarakat Bali baik berupa kredit mikro, konsumtif, KUR, dan sebagainya dengan tujuan akhir dapat membangun Bali dengan dana yang disalurkan tersebut. Dengan adanya kegiatan bank berupa pemberian kredit, maka bank dalam hal ini selain melakukan pemberian kredit, maka bank juga memasarkan produk - produk lainnya, seperti Tabungan, Deposito, Giro dan lain sebagainya. Sebagai salah satu bank kormesial, BPD memainkan peran yang sangat penting dalam perekonomian, terutama ekonomi regional. Peran ini terutama dilihat seberapa luas BPD dapat menerapkan fungsi perantara. Fungsi intermediasi dilakukan oleh BPD melalui proses pembelian kelebihan dana dari unit ekonomi (sektor bisnis, pemerintahan dan individu/rumah tangga) untuk didistribusikan ke unit ekonomi defisit.

Apakah pengaruh CAR, NIM, BOPO dan LDR secara simultan berpengaruh terhadap Non Performing Loan (NPL) di PT. Bank Pembangunan Daerah Bali ?

Apakah pengaruh CAR, NIM, BOPO dan LDR secara parsial berpengaruh terhadap Non Performing Loan (NPL) di PT. Bank Pembangunan Daerah Bali ?

Variabel manakah yang dominan mempengaruhi Non Performing Loan di PT. Bank Pembangunan Daerah Bali?

\section{TINJAUAN PUSTAKA}

\section{Bank}

Bank adalah suatu lembaga keuangan, yaitu suatu badan yang berfungsi sebagai financial intermediary atau perantara keuangan dari dua pihak, yakni pihak yang kelebihan dana dan pihak yang kekurangan dana. Signalling Theory atau teori sinyal dikembangkan oleh (Ross, 1977), menyatakan bahwa pihak eksekutif perusahaan memiliki informasi lebih baik mengenai perusahaannya akan terdorong untuk menyampaikan informasi tersebut kepada calon investor agar harga saham perusahaannya meningkat. Hal positif dalam signalling theory dimana perusahaan yang memberikan informasi yang bagus akan membedakan mereka dengan perusahaan yang tidak memiliki "berita bagus" dengan menginformasikan pada pasar tentang keadaan mereka, sinyal tentang bagusnya kinerja masa depan yang diberikan oleh perusahaan yang kinerja keuangan masa lalunya tidak bagus tidak akan dipercaya oleh pasar (Wolk dan Tearney dalam Dwiyanti, 2010).
Kata kredit berasal dari kata Credo artinya "Percaya". Pemperian kredit kepada debitur berdasarkan atas kepercayaan. Bank percaya bahwa kredit yang telah diberikan kepada debitur akan dapat dikembalikan di kemudian hari pada 15 saat jatuh tempo kredit, sesuai dengan kondisi yang tertulis dalam perjanjian kredit (pokok pinjaman, bunga pinjaman, jangka waktu kredit, tanggal jatuh tempo dan lain - lain).

\section{Non-Performing Loan (NPL)}

Menurut (Riyadi, 2004) rasio NonPerforming Loan merupakan perbandingan antara jumlah kredit yang diberikan dengan tingkat kolektibilitas yang merupakan kredit bermasalah dibandingkan dengan total kredit yang diberikan oleh bank.

Teori sinyal digunakan dalam penelitian ini karena NPL termasuk dalam laporan keuangan bank yang harus ditulis untuk transparasi kesehatan bank terhadap pihak-pihak yang memerlukan dalam rangka meningkatkan kepercayaan terhadap bank bersangkutan.

\section{Loan Deposit Ratio (LDR)}

Rasio LDR merupakan rasio perbandingan antara jumlah dana yang disalurkan ke masyarakat (kredit) dengan jumlah dana masyarakat dan modal sendiri yang digunakan. Rasio ini menggambarkan kemampuan bank membayar kembali penarikan yang dilakukan nasabah deposan dengan mengandalkan kredit yang diberikan sebagai sumber likuiditasnya. Semakin tinggi rasio ini semakin rendah pula kemampuan likuiditas bank (Dendawijaya, 2009).

\section{Capital Adequacy Ratio (CAR)}

Capital Adequacy Ratio menurut Lukman (Dendawijaya, 2009) adalah rasio yang memperlihatkan seberapa jauh seluruh aktiva bank yang mengandung risiko (kredit, penyertaan, surat berharga, tagihan pada bank lain) ikut di biayai dari dana modal sendiri bank disamping memperoleh dana-dana dari sumbersumber di luar bank, seperti dana dari masyarakat, pinjaman dan lain-lain.

\section{NIM/Net Interest Margin}

Net Interest Margin (NIM) adalah rasio yang digunakan untuk mengukur kemampuan manajemen bank dalam mengelola aktiva produktifnya untuk menghasilkan pendapatan bunga bersih. Pendapatan bunga bersih diperoleh dari pendapatan bunga dikurangi beban bunga. 


\section{Biaya Operasional Pendapatan Operasional (BOPO)}

BOPO (Biaya Operasional Pendapatan Operasional), yaitu rasio biaya operasional yang dikeluarkan untuk menghasilkan pendapatan operasional. Rasio BOPO ini berkaitan erat dengan kegiatan operasional bank, yaitu penghimpunan dana dan penggunaan dana. Biaya operasional bank yang terlalu tinggi atau sama dengan pendapatan operasional tidak akan mendatangkan keuntungan bagi bank.

\section{Publikasi penelitian sebelumnya}

(Adisaputra, 2012) dalam penelitian "Analisis Faktor - Faktor yang Mempengaruhi Non Performing Loan pada PT. Bank Mandiri (Persero) Tbk. Penelitian ini betujuan untuk menguji pengaruh Loan To Deposit Ratio (LDR), Capital Adequacy Ratio(CAR), Net Interest Margin (NIM), dan Efisiensi Operasi (BOPO) terhadap Non Performing Loan (NPL) sebagai proyeksi dari kinerja keuangan Bank Mandiri untuk meminimalisir masalah kredit yang terjadi dari periode Juni 2001 hingga Desember 2010. Hasil pengujian secara bersama-sama dimana variabel CAR, LDR, NIM dan BOPO memiliki pengaruh secara signifikan terhadap NPL pada PT. Bank Mandiri (Persero) Tbk. Sedangkan hasil penelitian secara parsial menunjukkan bahwa variabel CAR, LDR dan BOPO berpengaruh positif dan signifikanterhadap NPL, sementara NIM berpengaruh positif akan tetapi tidak signifikan terhadap NPL. Dari ketiga variable yang signifikan, variable CAR dan BOPO mempunyai pengaruh yang besar terhadap ROA yaitu dengan koefisien $1,203 \%$ dan $0,651 \%$. Dengan demikian pihak bank (emiten) diharapkan lebih memperhatikan tingkat efisiensi kredit untuk meminimalisir masalah kredit.

(Diyanti \& Widyarti, 2012) dalam penelitian "Analisis Pengaruh Faktor Internal dan Eksternal Terhadap Terjadinya NonPerforming Loan" Penelitian ini bertujuan mengetahui faktor-faktor internal dan faktorfaktor eksternal yang mempengaruhi terjadinya Non Performing Loan (studi kasus pada Bank Umum Konvensional di Indonesia penyedia layanan KPR periode 2008-2011). Dari hasil analisis menunjukkan bahwa Bank Size, Capital Adequacy Ratio (CAR), Pertumbuhan Gross Domestic Product (GDP) dan Laju Inflasi berpengaruh signifikan terhadap NonPerforming Loan (NPL). Kemampuan prediksi dari kelima variabel tersebut terhadap NonPerforming Loan (NPL) sebesar 30,4\%, sedangkan sisanya $69,6 \%$ dipengaruhi oleh faktor lain yang tidak dimasukkan ke dalam model penelitian.

Kurnia Dwi (Jayanti \& Haryanto, 2013) dalam penelitian "Analisis Faktor - Faktor yang Mempengaruhi Non-Performing Loan (Studi Pada Bank Umum Konvensional yang Go Publik di Indonesia Periode 2008 - 2012). . Hasil penelitian menunjukkan bahwa tidak ditemukan adanya penyimpangan terhadap uji asumsi klasik. Hal ini menunjukkan bahwa data yang tersedia normal atau memenuhi syarat untuk dijadikan model regresi linear berganda. Dari hasil analisis secara parsial variabel CAR berpengaruh negatif tidak signifikan terhadap NPL dan LDR berpengaruh positif tidak signifikan terhadap NPL, sedangkan variabel SIZE, KAP dan BOPO berpengaruh positif signifikan terhadap NPL. Hasil estimasi regresi menunjukkan kemampuan prediksi dari model ini sebesar 35\% sedangkan sisanya $65 \%$ dipengaruhi oleh faktor lain diluar model yang belum dimasukkan dalam penelitian ini.

(Dewi, 2009) dalam penelitian "Faktor Faktor Yang Mempengaruhi Strategi Pemberian Kredit dan Dampaknya Terhadap Non Performing Loan". Berdasarkan hasil pengujian hipotesis, maka terdapat beberapa implikasi manajerial yang dapat dilakukan berkaitan dengan penetapan strategi pemberian kredit untuk menekan/menurunkan NPL, yaitu mempertimbangkan faktor alam dalam strategi pemberian kredit di sektor pertanian, menganalisis kondisi ekonomi dan persaingan usaha saat ini dan melakukan forecasting / peramalan terhadap kondisi yang akan datang, melakukan pelatihan kepada AO untuk mempertajam analisis kredit, menjamin bahwa proses pengajuan dan pencairan kredit yang cepat dan mudah menyediakan berbagai alternatif pilihan bagi debitur untuk membayar kreditnya, menyediakan prosedur baku pemberian kredit, melakukan survey tempat usaha terhadap pengajuan kredit usaha, melihat dan menganalisis laporan keuangan dari usaha yang dijalankan oleh debitur, dan mencari informasi mengenai ada tidaknya ikatan antara debitur dengan lembaga keuangan yang lain, mengecek status usaha dan tempat tinggal debitur.

(Pratama, 2010) dalam penelitian "Analisis Faktor - Faktor Yang Mempengaruhi Kebijakan Penyaluran Kredit Perbankan (Studi pada Bank Umum di Indonesia Periode Tahun 2005 2009). Berdasarkan penelitian diperoleh hasil bahwa Dana Pihak Ketiga (DPK) berpengaruh positif dan signifikan terhadap penyaluran kredit perbankan. Capital Adequacy Ratio (CAR) dan Non Performing Loan (NPL) 
berpengaruh negatif dan signifikan terhadap penyaluran kredit perbankan. Sementara suku bunga Sertifikat Bank Indonesia (SBI) berpengaruh positif dan tidak signifikan terhadap penyaluran kredit perbankan. Untuk meningkatkan penyaluran kredit Bank Umum harus melakukan penghimpunan dana secara optimal, mengoptimalkan kegunaan sumber daya finansial (modal) yang dimiliki, dan memiliki manajemen perkreditan yang baik agar NPL tetap berada dalam tingkat yang rendah dan dalam batas yang disyaratkan oleh Bank Indonesia.

Andreani Caroline Barus dan Erick (2016) dalam penelitian "Analisis Faktor - Faktor Yang Mempengaruhi Non Performing Loan pada Bank Umum di Indonesia. Hasil penelitian menunjukkan bahwa secara simultan CAR, LDR, NIM, BOPO, Suku Bunga SBI, dan Inflasi berpengaruh terhadap NPL, sedangkan secara parsial LDR, NIM, BOPO, Suku Bunga SBI dan Ukuran Perusahaan berpengaruh signifikan positif sedangkan Inflasi berpengaruh signifikan negatif terhadap NPL, sedangkan CAR tidak berpengaruh signifikan terhadap NPL.

\section{METODE}

Populasi adalah wilayah generalisasi yang terdiri dari obyek atau subyek yang menjadi kuantitas dan karakteristik tertentu yang ditetapkan oleh peneliti untuk di pelajari dan kemudian ditarik kesimpulannya (Sugiyono, 2013). Berdasarkan uraian pengertian populasi, yang menjadi populasi dalam penelitian ini adalah Non Performing Loan (NPL) 2009 2017 di PT Bank Pembangunan Daerah Bali.

Metode pengumpulan data yang digunakan dalam penelitian ini adalah metode dokumentasi, yang merupakan cara pengumpulan data diperoleh dari informasi yang dikumpulkan dari dokumen-dokumen atau catatan-catatan dan membaca laporan-laporan yang telah disusun yang ada hubungannya dengan masalah yang diteliti (Sugiyono, 2013) pada penelitian sekarang dan laporan keuangan di PT. Bank Pembangunan Daerah Bali seperti : CAR, NIM, BOPO, LDR dan Non Performing Loan (NPL).

\section{Uji Asumsi Klasik}

Uji asumsi klasik adalah persyaratan statistik yang harus dipenuhi pada analisis regresi liniar berganda yang berbasis ordinary least square (OLS).Jadi analisis regresi yang tidak berdasarkan OLS tidak memerlukan persyaratan asumsi klasik, misalnya regresi logistic atau regresi ordinal. Demikian juga tidak semua uji asumsi klasik harus dilakukan pada analisis regresi linear, misalnya uji multikolinearitas tidak dilakukan pada analisis regresi linear sederhana dan uji autokorelasi tidak perlu diterapkan pada data cross sectional. Uji asumsi klasik, meliputi:

\section{Uji Normalitas}

Uji normalitas bertujuan untuk menguji apakah model regresi, variabel terikat dan variabel bebas keduanya mempunyai distribusi normal atau tidak. Model regresi yang baik adalah memiliki distribusi data atau normal atau mendekati normal.

\section{Uji Multikolinearitas}

Masalah - masalah yang mungkin akan timbul pada penggunaan persamaan regresi berganda adalah multikolinearitas, yaitu korelasi yang terjadi antara lebih dari dua variabel bebas atau satu variabel berkorelasi dengan variabel bebas lainnya.

\section{Uji Autokorelasi}

Autokolerasi dapat diartikan sebagai korelasi yang terjadi diantara anggota-anggota dari serangkaian observasi yang berderetan waktu (apabila datanya time series (apabila corss sectional ).

\section{Uji Heteroskedostisitas}

Uji ini bertujuan menguji apakah dalam model regresi terjadi ketidaksamaan variance dari residual satu pengamatan yang lain.

\section{Run Test}

Analisis Run Test termasuk dalam statistik nonparametrik. Uji ini digunakan untuk menguji pada kasus satu sampel. Sampel yang diambil dari populasi, apakah sampel yang diambil berasal dari sampel acak atau bukan.

\section{Analisis Regresi Linier Berganda}

Analisis ini untuk mengetahui besarnya pengaruh antara CAR, NIM, BOPO dan LDR secara simultan (bersama-sama) terhadap NPL. Regresi linier berganda dinyatakan dalam bentuk persamaan garis regresi linier berganda (Sugiyono, 2004).

\section{Uji Hipotesis \\ Uji F (Simultan)}

Uji $\mathrm{F}$ dilakukan untuk melihat pengaruh variabel bebas secara bersamasama terhadap variabel tidak bebas. 


\section{Uji T}

Uji t dilakukan untuk mengetahui pengaruh masing-masing variabel independen yang terdiri atas CAR, NIM, BOPO dan LDR terhadap NPL

Uji Koefisien determinasi (R2)

Digunakan untuk mengetahui keeratan hubungan antara variabel bebas dengan variabel terikat. Nilai $\mathrm{R}^{2}$ terletak antara 0 sampai dengan $1\left(0 \leq \mathrm{R}^{2} \leq 1\right)$. Tujuan menghitung koefisien determinasi adalah untuk mengetahui pengaruh variabel bebas terhadap variabel terikat.

Uji Standardized Coefficients (Beta)
Sebuah koefisien beta standar membandingkan kekuatan efek dari masingmasing variabel independen individu terhadap variabel dependen. Dengan kata lain, koefisien beta adalah semua variabel bebas yang pengaruhnya paling dominan. Pengaruh yang paling dominan adalah variabel yang mempunyai nilai terbesar.

\section{HASIL PENELITIAN DAN PEMBAHASAN}

\section{Hasil penelitian}

Uji asumsi klasik

Uji normalitas

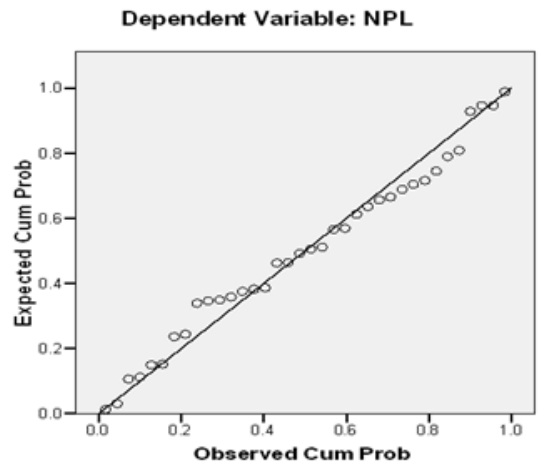

Gambar 1

Hasil uji normalitas

Sumber: Output SPSS

Data menyebar di sekitar garis diagonal dan mengikuti arah garis diagonal menunjukkan bahwa pola distribusi normal, maka model regresi memenuhi asumsi normalitas.

Uji multikolinearitas

Tabel 1

\section{Hasil uji multikolinearitas}

\begin{tabular}{|r|c|}
\hline \multicolumn{2}{|c|}{ Collinearity Statistics } \\
\hline Tolerance & \multicolumn{1}{|c|}{ VIF } \\
\hline & \\
, 950 & 1,053 \\
, 915 & 1,093 \\
, 889 & 1,125 \\
, 878 & 1,138 \\
\hline
\end{tabular}

VIF merupakan hasil uji asumsi klasik (uji multikolinearitas), apabila nilai tersebut lebih multikolinearitas. kecil dari 10 maka tidak ada gejala 
Uji autokorelasi

Tabel 2

\section{Hail uji autokorelasi}

\section{Model Summatry}

\begin{tabular}{|c|c|c|c|c|c|}
\hline Mode & $\mathrm{R}$ & R Square & $\begin{array}{l}\text { Adjusted } \\
\text { R Square }\end{array}$ & $\begin{array}{l}\text { std. Error of } \\
\text { he Estimate }\end{array}$ & $\begin{array}{l}\text { Durbin- } \\
\text { Watson }\end{array}$ \\
\hline 1 &, $700^{\mathrm{a}}$ &, 490 & $\begin{array}{l}, 424 \\
\end{array}$ & \begin{tabular}{|l|}
, 62034 \\
\end{tabular} &, 700 \\
\hline
\end{tabular}

Nilai dari Durbin-Watson sebesar $0,700-1,236$

dan ditabel untuk observasi sebanyak $36(n=36)$ dengan jumlah variabel $4(\mathrm{k}=4)$ diperoleh nilai $\mathrm{dL}=1.236$ serta nilai $\mathrm{dU}=1.724$. kesimpulan uji autokorelasi adalah dengan syarat :

$$
4-\mathrm{d}_{\mathrm{u}} \leq \mathrm{d} \leq 4-\mathrm{d}_{1} \quad=4-1,724 \leq 0,700 \leq 4
$$

Scatterplot

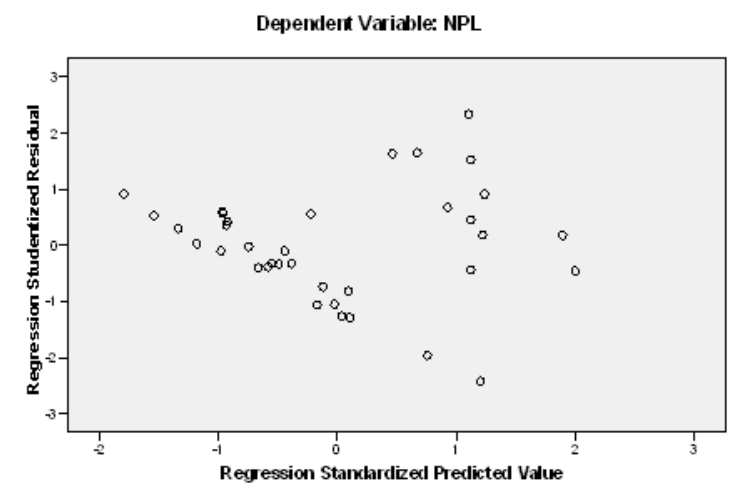

Gambar 2

Hasil Uji Heteroskedostisitas

Sumber : Output SPSS

Seluruh titik (data) menyebar merata baik dibawah nol dan diatas nol, maka diasumsikan bahwa data tersebut tidak ada gejala heteroskedastisitas.

Run Test

Tabel 3

Hasil Uji Runs Test

\begin{tabular}{|l|r|}
\multicolumn{2}{c}{ Runs Test } \\
\hline \multicolumn{1}{|c|}{} & $\begin{array}{c}\text { Unstandardiz } \\
\text { ed Residual }\end{array}$ \\
\hline Test Value &,- 00243 \\
Cases < Test Value & 18 \\
Cases > = Test Value & 18 \\
Total Cases & 36 \\
Number of Runs & 13 \\
Z & $-1,860$ \\
Asymp. Sig. (2-tailed) &, 063 \\
\hline
\end{tabular}

a. Median 
Hasil uji runs test menunjukan bahwa nilai asyimptotic significance sebesar 0,63 yang lebih besar dari 0,05. Jadi dapat disimpulkan bahwa secara keseluruhan tidak ada masalah autokorelasi

Analisis regersi linier berganda

Tabel 4

Hasil uji analisis regresi linier berganda

\begin{tabular}{|ll|r|r|r|r|r}
\hline \multirow{2}{*}{ Model } & \multicolumn{2}{|c|}{$\begin{array}{c}\text { Unstandardized } \\
\text { Coefficients }\end{array}$} & \multicolumn{2}{c|}{$\begin{array}{c}\text { Standardized } \\
\text { Coefficients }\end{array}$} & \multicolumn{1}{|c}{} \\
\cline { 3 - 4 } & & \multicolumn{1}{|c|}{ B } & Std. Error & \multicolumn{1}{c|}{ Beta } & \multicolumn{1}{c}{ t } & \multicolumn{1}{c}{ Sig. } \\
\hline 1 & (Constant) & $-6,967$ & 1,701 & & $-4,095$ &, 000 \\
& CAR &, 094 &, 029 &, 429 & 3,260 &, 003 \\
& NIM &, 003 &, 008 &, 040 &, 302 &, 765 \\
& BOPO &, 072 &, 024 &, 411 & 3,018 &, 005 \\
& LDR &, 019 &, 014 &, 181 & 1,322 &, 196 \\
\hline
\end{tabular}

a. Dependent Variable: NPL

\section{Sumber : Output SPSS}

maka persamaan regresinya menjadi:

$\mathrm{Y}=-6,967+0,094 \mathrm{X}_{1}+0,003 \mathrm{X}_{2}+$ $0,072 \mathrm{X}_{3}+0,019 \mathrm{X}_{4}+\mathrm{ei}$

Konstanta sebesar-6,967 ; artinya jika CAR (X1), NIM (X2), BOPO (X3) dan LDR (X4) nilainya adalah 0 , maka NPL (Y) nilainya turun sebesar $-696,7 \%$.

Koefisien regresi variabel CAR (X1) sebesar 0,094; artinya jika variabel independen lain nilainya tetap dan CAR mengalami kenaikan 1\%, maka NPL (Y) akan mengalami peningkatan sebesar 9,4\%. Koefisien bernilai positf artinya terjadi hubungan positif antara CAR dengan NPL, semakin naik CAR maka semakin meningkat NPL.

Koefisien regresi variabel NIM (X2) sebesar 0,003; artinya jika variabel independen lain nilainya tetap dan NIM mengalami kenaikan 1\%, maka NPL (Y) akan mengalami peningkatan sebesar $0,3 \%$. Koefisien bernilai positif artinya terjadi hubungan positif antara
NIM dengan NPL, semakin naik NIM maka semakin meningkat NPL.

Koefisien regresi variabel BOPO (X3) sebesar 0,072; artinya jika variabel independen lain nilainya tetap danBOPO mengalami kenaikan $1 \%$, maka NPL (Y) akan mengalami peningkatan sebesar 7,2\%. Koefisien bernilai positif artinya terjadi hubungan positif antara BOPO dengan NPL, semakin naik BOPO maka semakin meningkat NPL.

Koefisien regresi variabel LDR (X4) sebesar 0,019; artinya jika variabel independen lain nilainya tetap dan LDR mengalami kenaikan 1\%, maka NPL (Y) akan mengalami peningkatan sebesar $1,9 \%$. Koefisien bernilai positif artinya terjadi hubungan positif antara LDR dengan NPL, semakin naik LDR maka semakin meningkat NPL.

Uji hipotesis

Uji F

Tabel 5

Hasil uji F

\begin{tabular}{|c|c|c|c|c|c|c|}
\hline \multicolumn{7}{|c|}{ ANOVA } \\
\hline \multicolumn{2}{|c|}{ Model } & $\begin{array}{l}\text { Sum of } \\
\text { Squares }\end{array}$ & df & hean Square & $\mathrm{F}$ & Sig. \\
\hline \multirow[t]{3}{*}{1} & Regressid & 11,471 & 4 & 2,868 & 7,452 &, $000^{a}$ \\
\hline & Residual & 11,930 & 31 & ,385 & & \\
\hline & Total & 23,401 & 35 & & & \\
\hline
\end{tabular}

Sumber : Output SPSS 
Uji F (sig.). nilai sig. sebesar 0,000 lebih kecil dari 0,05 yang berarti seluruh variabel independen (CAR, NIM, BOPO dan LDR) mempunyai hubungan liner / pengaruh dengan variabel. Berdasarkan hasil keseluruhan pengujian di atas, ternyata dengan tingkat keyakinan $95 \%$, kesalahan $5 \%$ dan derajat bebas pembilang 4 dan derajat pengebut 31 , diperoleh nilai F-hitung sebesar 7,452 dan nilai
F-tabel sebesar 2,68 sehingga jika dibandingkan maka nilai F-hitung lebih besar dari F-tabel dan F-hitung berada pada daerah penolakan Ho dan sig adalah 0.000 . Oleh karena nilai sig kurang dari nilai $\alpha=0.05$ maka Ho ditolak dan $\mathrm{H} 1$ diterima. Ini berarti bahwa CAR, NIM, BOPO dan LDR terhadap NPL berpengaruh positif dan signifikan secara silmutan.

Tabel 6

Hasil uji T

\begin{tabular}{|c|c|c|c|c|c|c|}
\hline \multirow[b]{2}{*}{ Model } & & \multicolumn{2}{|c|}{$\begin{array}{l}\text { Unstandardized } \\
\text { Coefficients }\end{array}$} & \multirow{2}{*}{$\begin{array}{c}\begin{array}{c}\text { Standardized } \\
\text { Coefficients }\end{array} \\
\text { Beta }\end{array}$} & \multirow[b]{2}{*}{$t$} & \multirow[b]{2}{*}{ Sig. } \\
\hline & & B & Std. Error & & & \\
\hline & (Constant) & $-6,967$ & 1,701 & & $-4,095$ &, 000 \\
\hline & CAR &, 094 &, 029 & ,429 & 3,260 &, 003 \\
\hline & NIM & ,003 & ,008 &, 040 & ,302 & ,765 \\
\hline & BOPO &, 072 &, 024 &, 411 & 3,018 &, 005 \\
\hline & LDR & 019 &, 014 & ,181 & 1,322 & , 196 \\
\hline
\end{tabular}

a. Dependent Variable: NPL

\section{Sumber : Output SPSS}

Berdasarkan hasil tabel 6 , ternyata dengan tingkat keyakinan 95\%, kesalahan 5\% diperoleh nilai sig untuk CAR dimana nilai sig $=0,003<$ 0,05 dan hasil uji CAR (X1) menunjukan thitung 1 lebih besar dari t-tabel maka $\mathrm{HO}$ ditolak H1. Ini berarti bahwa CAR berpengaruh positif dan signifikan terhadap NPL.

Berdasarkan hasil Tabel 6, ternyata dengan tingkat keyakinan 95\%, kesalahan 5\% diperoleh nilai sig untuk NIM dimana nilai sig $=0,765>$ 0,05 dan NIM (X2) t-hitung 1 lebih kecil. Ini berarti bahwa NIM berpengaruh positif dan tidak signifikan terhadap NPL.

Berdasarkan hasil tabel 6 , ternyata dengan tingkat keyakinan 95\%, kesalahan 5\% diperoleh nilai sig untuk BOPO dimana nilai sig $=0,005$ dan BOPO (X3) t-hitung 1 lebih besar dari ttabel ,H0 ditolak H1 diterima. Ini berarti bahwa BOPO berpengaruh positif dan signifikan terhadap NPL.

Berdasarkan hasil Tabel 6 , ternyata dengan tingkat keyakinan 95\%, kesalahan 5\% diperoleh nilai sig untuk LDR dimana nilai sig $=0,196$ dan LDR (X4) t-hitung 1 lebih kecil dari t-tabel maka H0 ditolak H1 diterima. Ini berarti bahwa LDR berpengaruh positif dan tidak signifikan terhadap NPL.

\section{Uji Koefisien determinasi $\left(\mathrm{R}^{2}\right)$}

Nilai adjusted $\mathrm{R}$ square yang sering juga

Tabel 7

Model Summatry

\begin{tabular}{|c|c|c|c|c|c|}
\hline Mode & $\mathrm{R}$ & R Square & $\begin{array}{l}\text { Adjusted } \\
\text { R Square }\end{array}$ & $\begin{array}{l}\text { Std. Error of } \\
\text { he Estimate }\end{array}$ & $\begin{array}{l}\text { Durbin- } \\
\text { Watson } \\
\end{array}$ \\
\hline 1 & ,700a &, 490 &, 424 & \begin{tabular}{|l|}
, 62034 \\
\end{tabular} &, 700 \\
\hline
\end{tabular}

a. Predictors: (Constant), LDR, CAR, NIM , BOPO

b.Dependent Variable: NPL

\section{Sumber : Output SPSS}

disebut dengan kofisien determinasi yang menyatakan seberapa besar variabel bebas (CAR, NIM, BOPO dan LDR) mampu menjelaskan variabel terikat (NPL), hasil analisis koefisien determinasi sebesar 0.424 yang berarti $42,4 \%$ CAR, NIM, BOPO dan LDR mampu menjelaskan NPL, sedangkan sisanya
$57,6 \%$ dijelaskan oleh variabel lainnya yang tidak dimasukan dalam model variabel.

Uji Standardized Coefficients (Beta)

Berdasarkan tabel 8 dapat diketahui bahwa 


\section{Tabel 8}

Uji Standardized Coefficients (Beta)

\begin{tabular}{|ll|r|r|r|}
\hline \multirow{2}{*}{ Model } & \multicolumn{2}{|c|}{$\begin{array}{c}\text { Unstandardized } \\
\text { Coefficients }\end{array}$} & $\begin{array}{c}\text { Standardized } \\
\text { Coefficients }\end{array}$ \\
\cline { 3 - 5 } & \multicolumn{1}{|c|}{ B } & \multicolumn{1}{c|}{ Std. Error } & \multicolumn{2}{c|}{ Beta } \\
\hline 1 & (Constant) & $-6,967$ & 1,701 &, 429 \\
& CAR &, 094 &, 029 &, 040 \\
& NIM &, 003 &, 008 &, 411 \\
& BOPO &, 072 &, 024 &, 181 \\
\hline \multicolumn{2}{|c|}{ LDR } &, 019 &, 014 & \\
\multicolumn{2}{|c|}{ a. Dependent Variable: NPL }
\end{tabular}

a. Dependent Variable: NPL

\section{Sumber : Output SPSS}

variabel yang mempunyai nilai terbesar adalah variabel CAR sebesar 0,429. Ini berarti bahwa variabel CAR mempunyai pengaruh dominan terhadap NPL di PT. Bank Pembangunan Daerah Bali.

\section{PEMBAHASAN}

\section{Pengaruh Inflasi (X1) terhadap Volume Simpanan Masyarakat.}

Berdasarkan analisis regresi linier berganda di peroleh hasil sebagai berikut :

\section{Variabel CAR.}

Pada variabel CAR diperoleh nilai koefisien regresi sebesar 0,094 $(\mathrm{b} 1=0,094)$ dan nilai sig $=0,003$. Ini berarti bahwa CAR berpengaruh positif dan signifikan terhadap NPL. Secara teori menunjukan bahwa CAR berpengaruh negatif terhadap NPL. Menurut Ali (2004) semakin tinggi CAR, maka semakin menurun sumber daya financial yang dapat digunakan untuk keperluan pengembangan usaha dan mengantisipasi potensi kerugian yang diakibatkan oleh penyaluran kredit. Artinya CAR berpengaruh negatife terhadap NPL. Tetapi pada tabel coefficients variabel CAR memiliki pengaruh positif dan signifikan terhadap NPL. CAR pengaruh positif artinya jika CAR meningkat makan NPL juga meningkat. Hal ini bisa disebabkan CAR adalah rasio kecukupan modal, jika CAR dipergunakan dengan baik dan tidak berlebihan maka tidak akan menyebabkan terjadinya kerugian yang akan menyebabkan NPL bermasalah dan tingkat kepercayaan masyarakat pada bank akan bagus dan meningkat. Begitu juga sebaliknya jika CAR digunakan dengan cara tidak baik atau berlebihan maka akan berdampak pada NPL itu sendiri dan akan semakin tinggi juga risiko kredit bermaslah pada bank. Jadi initinya tergantung pada pihak bank itu sendiri.

Hasil penelitian ini mengonfrimasi hasil penelitian sebelumnya oleh (Diyanti \& Widyarti, 2012) dalam penelitian yang berjudul
“Analisis Pengaruh Faktor Internal Dan Eksternal Terhadap Terjadinya Non-Performing Loan, penelitian (Adisaputra, 2012) dalam penelitian yang berjudul "Analisis Faktor - Faktor yang Mempengaruhi Non Performing Loan pada PT. Bank Mandiri (Persero) Tbk, dan jurnal (Dendawijaya, 2009) menyimpulkan bahwa CAR berpengaruh negative terhadap kondisi bermasalah. Jadi hasil dari data diatas menunjukan bahwa tergantung penggunaannya, kalau penggunaan CAR berlebihan akan mengakibatkan masalah. Jadi kalau CAR meningkat maka NPL cenderung menurun, begitu juga sebaliknya kalau CAR menurun makan NPL cenderung meningkat.

\section{Variabel NIM.}

Menurut (Pandia, 2012) semakin besar rasio NIM maka meningkatkan pendapatan bunga atas aktiva produktif yang dikelola bank sehingga kemungkinan suatu bank dalam kondisi bermaslah semakin kecil. Pada tabel coefficients variabel NIM berpengaruh positif dan tidak signifikan. Dengan tingkat keyakinan $95 \%$, kesalahan $5 \%$ diperoleh nilai sig adalah 0,765 dan hasil uji NIM (X2) menunjukan thitung 1 lebih kecil dari t-tabel maka $\mathrm{H} 0$ diterima H1 ditolak. Ini berarti bahwa NIM berpengaruh positif dan tidak signifikan terhadap NPL. Hasil penelitian ini mengonfrimasi peneliti sebelumnya oleh (Aini, 2013), yang menyatakan bahwa NIM berpangurh positif dan tidak signifikan. Kondisi ini menunjukan bahwa semakin besar NIM tidak diikuti dengan semakin besarnya NPL. Hal ini memungkinkan karena NIM adalah rasio yang digunakan untuk mengukur kemampuan manajemen bank dalam mengelola aktiva produktifnya untuk menghasilkan pendapatan bunga bersih. NIM tidak signifikan terhadap NPL disebabkan oleh perbedaan periode penelitian dan penyebab lainnya adalah besarnya rata - rata NIM yang didapat dari sampel data yang ada yaitu $9,98 \%$ artinya PT. Bank Pembangunan Daerah Bali melebihi kriteria NIM yang di tentukan oleh Bank Indonesia Adapun standar yang ditetap- 
kan Bank Indonesia untuk ratio Net Interest Margin (NIM) adalah 6\%.

\section{Variabel BOPO.}

Menurut (Dendawijaya, 2009) semakin kecil rasio ini berarti semakin efisien biaya operasional yang dikeluarkan bank yang bersangkutan. Pada tabel coefficients variabel BOPO berpengaruh positif dan signifikan. Dengan tingkat keyakinan 95\%, kesalahan 5\% diperoleh nilai sig adalah 0,005 dan hasil uji BOPO (X3) menunjukan t-hitung 1 lebih besar dari t-tabel maka $\mathrm{H} 0$ ditolak $\mathrm{H} 1$ diterima. Ini berarti bahwa BOPO berpengaruh positif dan signifikan terhadap NPL.

Hasil penelitian ini mengonfrimasi hasil penelitian sebelumnya oleh (Dendawijaya, 2009) BOPO ini digunakan unuk mengukur tingkat efisiensi dan kemampuan bank dalam melakukan kegiatan operasinya. Dan menurut ketentuan Bank Indonesia efisiensi operasi diukur dengan BOPO dengan batas maksimum BOPO adalah $90 \%$. Jadi ketika pendapatan bank tinggi dengan biaya operasional yang rendah dapat menekan rasio BOPO sehingga bank berada pada posisi sehat, yang artinya kecenderungan untuk meminimlisir terjadinya kredit macet dapat diatasi.

\section{Variabel LDR.}

Menurut (Dendawijaya, 2009) semakin tinggi rasio ini maka semakin rendah pula kemampuan likuiditas bank. Pada tabel coefficients variabel LDR berpengaruh positif dan tidak signifikan. Dengan tingkat keyakinan 95\%, kesalahan 5\% diperoleh nilai sig adalah 0,196 dan hasil uji LDR (X4) menunjukan thitung 1 lebih kecil dari t-tabel maka H0 ditolak H1 diterima. Ini berarti bahwa LDR berpengaruh positif dan tidak signifikan terhadap NPL. Hasil penelitian ini mengonfrimasi hasil penelitian sebelumnya oleh (Diyanti \& Widyarti, 2012) yang menyatakan bahwa LDR berpengaruh positif dan tidak signifikan. Hasil ini menerima teori yang ada bahwa semakin tinggi LDR maka semakin tinggi juga NPL, hanya saja tidak signifikan. Artinya tidak seluruhnya dana pihak ketiga yang ditempatkan di kredit atau dalam kata lain hanya sebagaian kecil dana pihak ketiga ditempatkan di kredit.

Berdasarkan nilai Adjusted $\mathrm{R}$ Square menyatakan seberapa besar variabel bebas (CAR, NIM, BOPO dan LDR) mampu menjelaskan variabel terikat (NPL), hasil analisis koefisien determinasi sebesar 0.424 yang berarti $42,4 \%$ CAR, NIM, BOPO dan LDR mampu menjelaskan NPL, sedangkan sianya $57,6 \%$ dijelaskan oleh variabel lainnya yang tidak dimasukan dalam model variabel. Itu artinya ada factor lain yang mempengaruhi NPL.

\section{SIMPULAN}

Berdasarkan hasil penelitian dan hasil analisis yang telah dikemukaan pada bab sebelumnya, dapat disimpulkan sebagai berikut : Berdasarkan hasil uji regresi secara silmutan (Uji F) maka dapat disimpulkan bahwa CAR, NIM, BOPO dan LDR berpengaruh signifikan terhadap Non Performing Loan (NPL) di PT. Bank Pembangunan Daerah Bali tahun 2009 - 2017. Berdasarkan hasil pengujian parsial (Uji t) diketahui bahwa CAR berpengaruh nyata dan signifikan terhadap Non Performing Loan (NPL) di PT Bank Pembangunan Daerah Bali tahun 2009 - 2017, NIM berpengaruh positif dan tidak signifikan terhadap Non Performing Loan (NPL) di PT Bank Pembangunan Daerah Bali tahun 2009 - 2017, BOPO berpengaruh positif dan signifikan terhadap Non Performing Loan (NPL) di PT Bank Pembangunan Daerah Bali tahun 2009 - 2017, sedangkan LDR berpengaruh positif dan tidak signifikan terhadap Non Performing Loan (NPL) di PT Bank Pembangunan Daerah Bali tahun 2009 2017. Berdasarkan hasil penelitian Uji Standardized Coefficient (Beta) variabel yang dominan mempengaruhi Non Performing Loan (NPL) adalah variabel CAR dengan nilai Beta sebesar $0,429 \%$ di bandingkan dengan NIM sebesar $0,040 \%$, BOPO sebesar $0,411 \%$ dan LDR sebesar $0,181 \%$.

\section{DAFTAR PUSTAKA}

Adisaputra, I. (2012). Analisis Faktor-Faktor Yang Mempengaruhi Non Performing Loan Pada PT. Bank Mandiri (Persero) Tbk. Universitas Hasanuddin Makasar. Retrieved from http:// repository.unhas.ac.id/bitstream/ handle/123456789/1596/SKRIPSI LENGKAP -FEB-MANAJEMENIKSAN ADISAPUTRA.pdf? sequence $=1$

Aini, N. (2013). Pengaruh Car, Nim, Ldr, Npl, Bopo, Dan Kualitas Aktiva Produktifterhadap Perubahan Laba (Studi Empiris Pada Perusahaan Perbankan yang terdaftar di BEI) Tahun 2009-2011. Dinamika Akuntansi, Keuangan Dan Perbankan, 2(1), 14-25. Retrieved from https:// www.unisbank.ac.id/ojs/index.php/fe9/ article/download/2104/772 
Dendawijaya, L. (2009). Manajemen Perbankan. Jakarta: Ghalia Indonesia.

Dewi, C. (2009). ). Faktor-Faktor Yang Mempengaruhi Strategi Pemberian Kredit Dan Dampaknya Terhadap Non Perfoming Loan (Studi Kasus Pada Bank Perkreditan Rakyat Di Propinsi Jawa Tengah). Pascasarjana Universitas Diponegoro.

Diyanti, A., \& Widyarti, E. T. (2012). Analisis Pengaruh Faktor Internal dan Eksternal terhadap terjadinya NonPerforming Loan (Studi Kasus pada Bank Umum Konvensional yang Menyediakan Layanan Kredit Pemilikan Rumah Periode 2008-2011).

Jayanti, K. D., \& Haryanto, A. M. (2013). Analisis Faktor-Faktor Yang Mempengaruhi Non-Performing Loan (Studi Pada Bank Umum Konvensional yang Go Public di Indonesia Periode 2008-2012).

OJK (Otoritas Jasa Keuangan). "Laporan Keuangan Bank". 5 Oktober 2018. https:// ojk.go.id/.

Pandia, F. (2012). Manajemen Dana dan Kesehatan Bank. Jakarta: Rineka Cipta.

Pratama, B. A. (2010). Analisis faktor-faktor yang mempengaruhi kebijakan penyaluran kredit perbankan (Studi pada Bank Umum di Indonesia Periode Tahun 2005-2009). Universitas Diponogoro.

PT. Bank Pembangunan Daerah Bali. "Laporan Pelaksanaan Tata Kelola Bank BPD Bali Tahun 2016". 7 Januari 2019. www.bpdbali.co.id/assets/CKImages/ files/Tata Kelola 2016.

PT. Bank Pembangunan Daerah Bali. "Struktur Organisasi ". 10 Desember 2018. https://www.bpdbali.co.id/page/6/ STRUKTUR-ORGANISASI.html.

Riyadi, S. (2004). Manajemen Aset dan Liabilitis Perbankan. Jakarta: LPFEUI.

Sugiyono. (2013). Metode Penelitian Bisnis. Bandung: Alfabeta.

Sugiyono, D. R. (2004). Metode Penelitian. Bandung: CV Alvabeta.

Undang-undang Republik Indonesia Nomor 7 tahun 1992. "Perbankan". 5 Oktober 2018. Http://www.bi.go.id/id/tentangbi/uu-bi/Documents/uu_bi 